\title{
Stability and resilience in macrobenthic communities: the role of habitat disturbance
}

\author{
C. Guerra ${ }^{1}$, F. Cobo $^{2}$, M. González ${ }^{2}$ \& J. Alonso ${ }^{1}$ \\ ${ }^{I}$ Escola Superior Agrária, Instituto Politécnico de Viana do Castelo, \\ Portugal \\ ${ }^{2}$ Laboratorio de Hidrobioloxía, Dpto. de Bioloxía Animal, \\ Univ. Santiago de Compostela, Spain
}

\begin{abstract}
The diversity of fluvial ecosystems allows the detection of various changes in the natural equilibrium. These changes can be related to variations in the composition of the fluvial forest, to the chemical or physical quality of the water, or to alterations of the habitat template. The aim of this study was to understand the resilience of the ecosystem to the degradation of the habitat, resulting from the construction of a highway in a regional protected area. This resilience was measured in terms of the reestablishment of macrobenthic communities. Located at the Estorãos River (sub-watershed of the Lima River, NW Portugal), a set of three sampling stations upstream and downstream from the construction site were monitored for a period of one year, and the invertebrate communities were characterized as well as their ecological and biological traits, and the changes that occurred were classified. The observations made clearly mark the moment of the beginning of the construction process, and from the trait analysis we could discriminate between different types of pressures, namely an increment on sediment loads, and riverbed deterioration. This impact also affected the trophic relations and the food preferences of the invertebrate communities. From the analysis it is apparent that the fact that the construction was done in late winter contributed to the reestablishment of the invertebrate communities, since construction didn't affect their sensitive reproduction period. This fact permitted full recolonization of the construction site in a period of four months, reestablishing the community at the same diversity levels as the reference sites. All these aspects are in agreement with the components being analysed, but they lack information from the longer time series and more ecological components are needed to classify the resilience capacity of this type of ecosystem.

Keywords: habitat disturbance, fluvial ecosystem resilience, environmental impact, macroinvertebrate communities.
\end{abstract}




\section{Introduction}

During the last century humanization processes and landscape change have increased, resulting in considerable spatial diversity. This poses a methodological challenge when assessing ecosystem vulnerability and resilience, with regard to changes in land use and land cover [1]. In this sense, these changes can lead to an increase in the magnitude and scale of environmental impacts, and enhance the importance and complexity of the evaluation processes.

Land-use practices play a major role in the health and dynamics of aquatic ecosystems [29, 33-35]. Rivers are important vectors of stability, for landscape evolution and management, functioning as dispersal corridors for both fauna and flora. In this capacity rivers act as buffers against intense environmental impacts, favoring the recolonization of impaired areas downstream. This downstream recolonization is achieved by active locomotion processes (e.g. drift) [2], which are important ecological phenomenon in running waters [3] for understanding the colonization cycle [4], and evaluating the potential impact of certain actions.

In this context discrete events can play a specific role in structuring most ecological communities, particularly stream benthic communities [5]. One of the most common approaches is to track human-induced change by the abundances of indicator taxa [12], and many studies have been conducted to relate different types of disturbance with species traits and community shaping [7]. In this context, the ecological functions of streams can be described by a multitude of general biological traits that reflect the adaptation of species or communities to environmental conditions [8-10,30].

Community traits can act as indicators of environmental change [14-16], mapping the variations of the ecosystems and their functions. From the analysis of community traits it is possible to predict the health and fitness of an ecosystem, by measuring the environmental impact of human actions.

Managers and scientists conducting field assessments of environmental impacts must isolate the effect being studied from the "noise" caused by natural spatial and temporal variation.

In this sense, society has agreed many times about the objectives of ecosystem management, but narrowly defined ecosystem management is unlikely to succeed [11], and methodological measures must be implemented.

\section{Methodology}

We have studied a set of three sampling stations located along a small watershed (River Estorãos Watershed) in the NW of Portugal, fig. 1. The watershed is characterized by a great heterogeneity of natural and human conditions [17], leading to diversified land use of the rural landscape. The construction of a major road can then be translated as severe humanization, conditioning the ecological processes in the area.

Collections were taken four times from each of the sampling stations over a period of one year, matching the events that occurred before and after the construction took place. This allowed us to point out the differences between the 
stations over time, fig. 2. The samples were collected using a kicknet sampler, sampling all the representative habitats within the site area.

To better understand the differences that occurred, we used a set of diversity measures (e.g. Simpson's diversity index) as well as "between sites" metrics and similarity coefficients $[20,31,32]$. This process has the objective of indicating the relationships present in the field but also of evaluating these methods for future use in rapid bio-assessment of construction impaired sites.
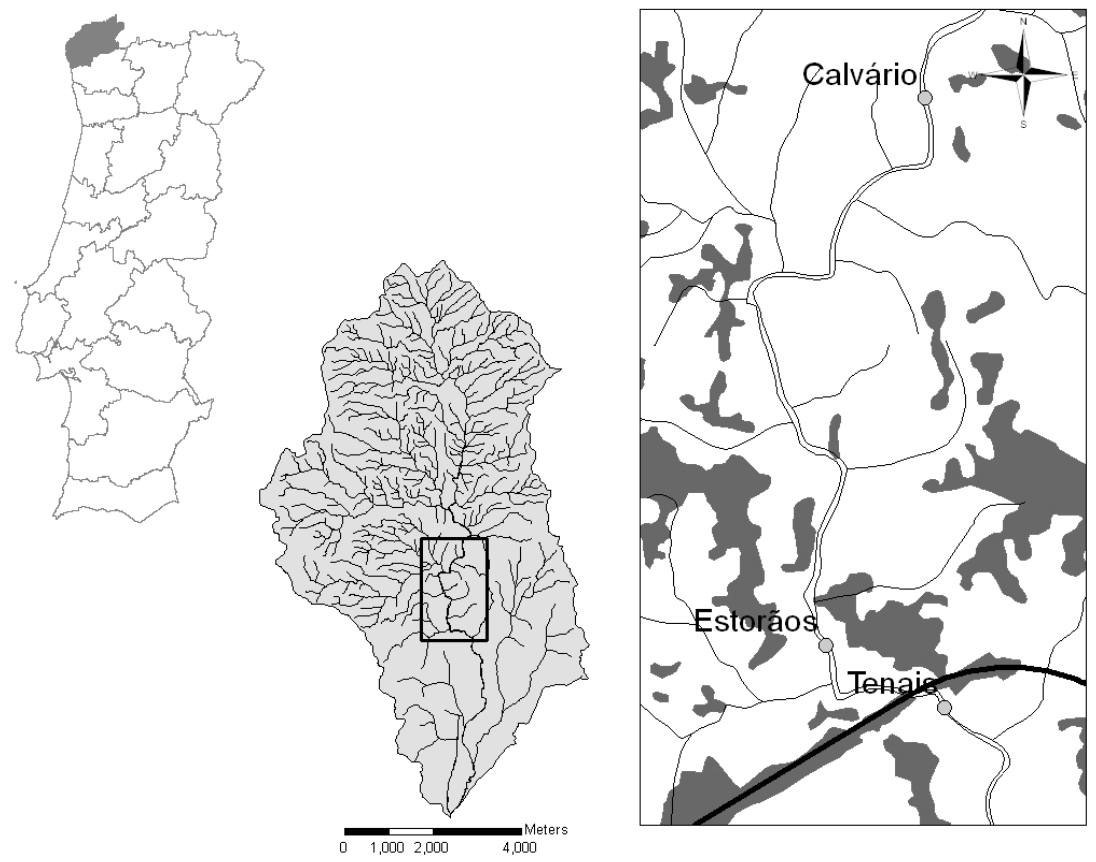

Figure 1: Geographic location of the surveyed field stations.

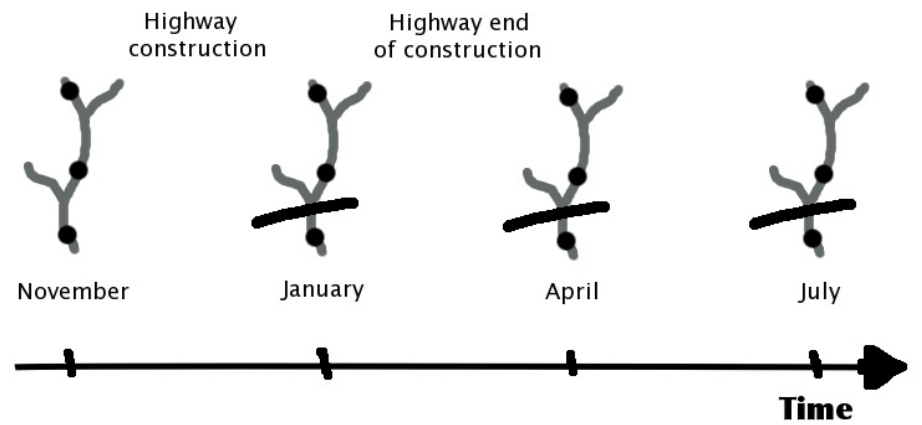

Figure 2: Relations between the different scales of analysis, and the chain of events. 
For a more specific analysis, we used the methods presented by Tachet and other authors $[18,19,21,22]$ to analyze species traits using fussy analysis. This analysis allows us to establish the relationships between habitat loss and community adaptations. These relationships between habitat and biological communities [8, 26-28] have been referred to by Scarsbrook and Townsend [25] as a filtering effect that is reflected at community level.

\section{Results}

From the analysis of the invertebrate communities, it is also possible to observe a clear break, regarding Tenais station, of the diversity as well as richness levels between November and April, fig. 3. This difference appears to be related to the impacts produced by the construction of the highway, because when the construction process stopped, both values rose to a more stable level.

Further analysis of species traits, fig. 4, has also revealed that while the construction site was active, the community changed, becoming more adapted to the resulting conditions of stress.
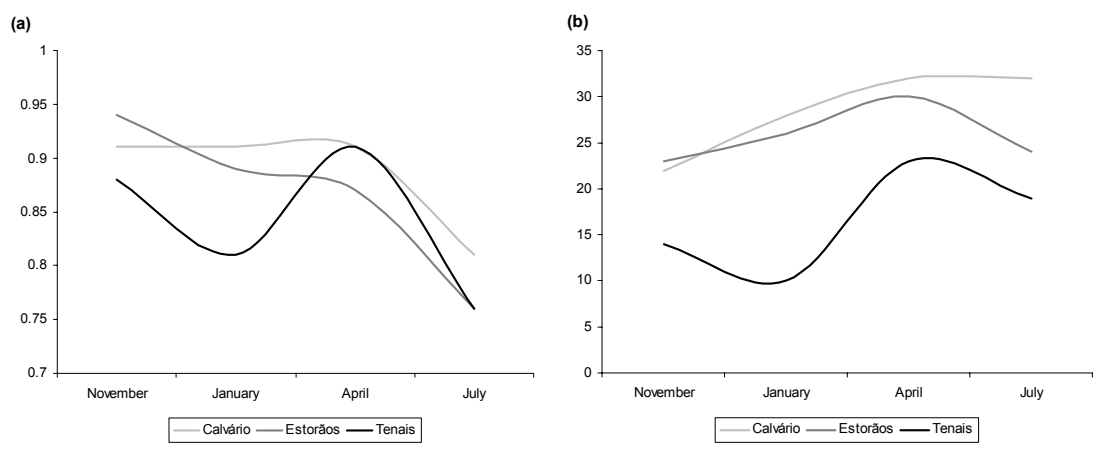

Figure 3: $\quad$ Representation of (a) diversity (Simpson's diversity index) and (b) richness (total number of taxa) measures.

In this sense, the community changes appear reflected not only on the loss of taxa, but also on community characteristics. Community characteristics related to sediment loads (e.g. food [preference for fine sediment or detritus]) or habitat homogenization (e.g. substrate preferendum [preference for sand or silt]) were incremented.

Due to the seasonal timing of construction and the ensuing and rapid reestablishment of the river conditions the colonization process was effective, even though there was a break between April and July, fig. 5.

This break in the recolonization process could be the result of a small dam located between Calvário and Estorãos. In winter the dam is open, allowing the passage (drift) of invertebrate fauna. In summer, the floodgates are closed for entertainment purposes (e.g. fluvial beach), and the flow is very limited. 


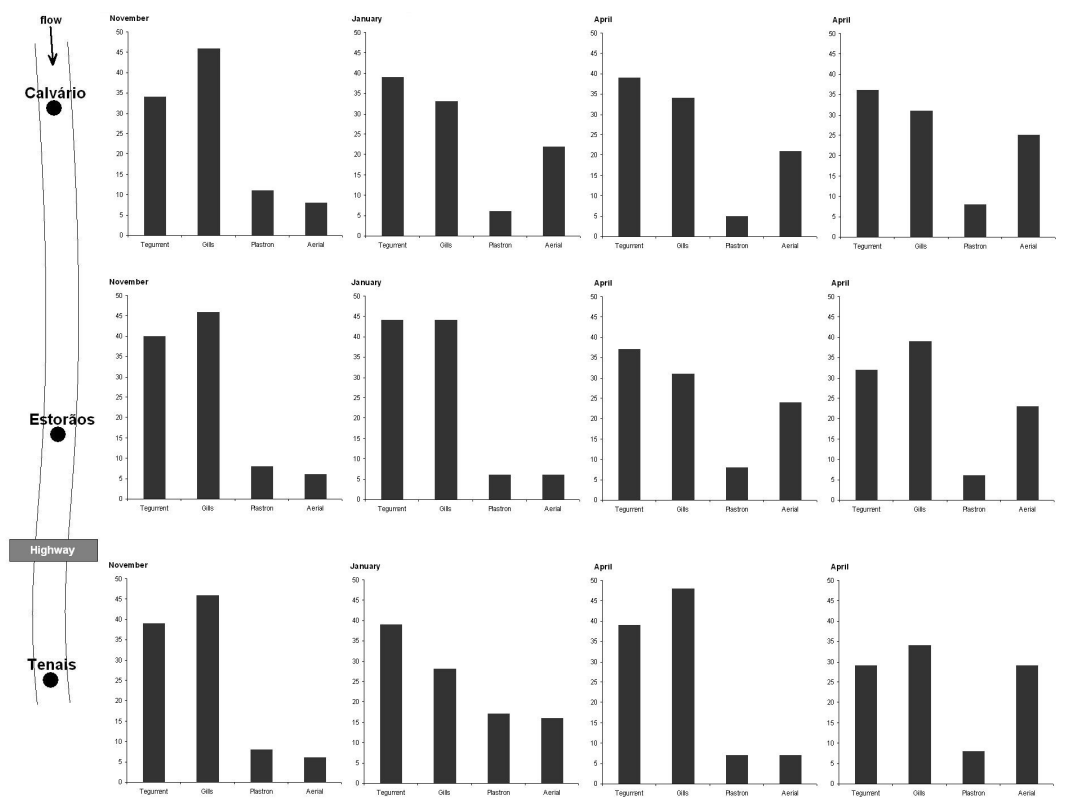

Figure 4: An example of traits evaluation by frequency analysis: respiration.

\section{Sorensen}

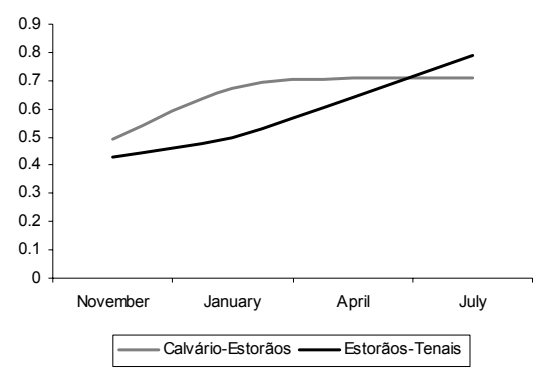

\section{Exclusive taxa}

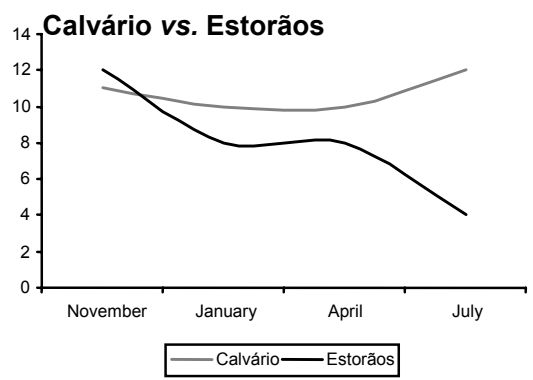

\section{Common taxa}
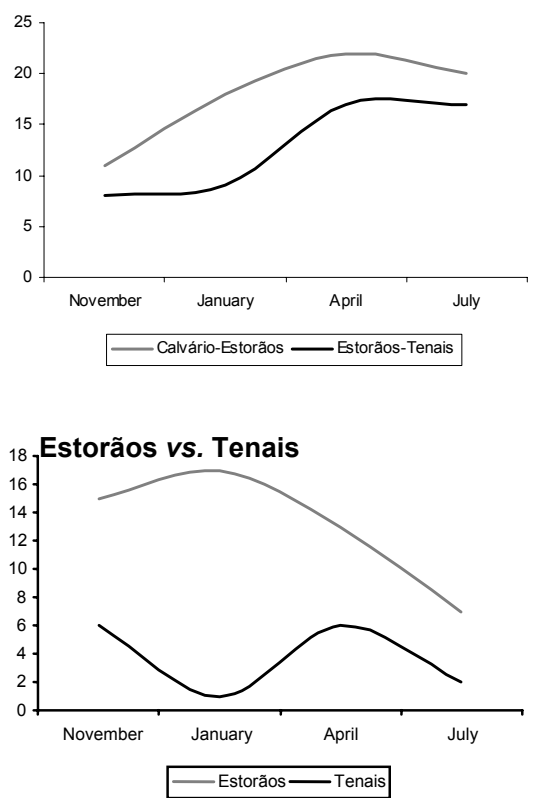

Figure 5: Similarity analysis regarding the comparison of the taxa composition. 
The resulting bottleneck effect increases the homogenization of the downstream communities. In this case homogenization processes result in highly correlated loss of taxa between Estorãos and Tenais.

\section{Discussion}

Human impact on rivers and fluvial ecosystems is increasing, reducing their ecological function almost to the river channel only. In this sense, rivers are corridors that connect many different ecosystems (e.g. inland waters - sea waters; land ecosystem - water ecosystem) and their functions must be protected.

The construction of a major road as well as other heavy constructions, implies severe impacts on habitats and consequently on the stability of biotic communities. These impacts can be reduced by managing the construction time frame and the opening of "ecological windows" that minimize community losses.

In many ways, the importance of environmental impact evaluation and management is clear, but the need for a priori studies is often neglected. This study has demonstrated that the disturbance of ecosystems can be identified at various levels and can be related to a broad spectrum of potential sources of impact. In this sense, is important to not only predict the environmental impact of a certain action, but also to monitor the environmental changes and their reflections on the ecosystem.

The stability and resilience of the aquatic communities is also affected when major disturbing events take place. In this case, after the construction of the road, the resilience of the community seemed to be sufficient to reestablish stability in a short period of time. Although this was the case, our observations indicate that the events that occurred after the construction, greatly contributed to the loss of stability and equilibrium in the invertebrate communities.

In this context, the differences in summer between Calvário and the remaining stations can only be explained by an increment of abiotic pressure, resulting from man's misuse of rivers and fluvial ecosystems. Many studies have pointed the ecological consequences of constructions that covering rivers and riverbeds $[6,13,23,24]$, but can a small, almost temporary dam result in a significant community loss?

In this case it seams that the observed loss of taxa, though it increased through the construction of the highway, it was related to the dam's regulation process during summer. The resulting habitat loss, as well as the interruption of drift processes, had severe consequences to both fauna and flora communities, resulting in poorer and more unstable ecosystems. As we stated earlier, this kind of impact can and should be predicted, since it is a way to propose measures that mitigate effects and adjust construction procedures accordingly.

\section{References}

[1] Mücher, C.A., Bunce, R.G., Jongman, R.H., Klijn, J.A., Koomen, A.J., Metzger, M. \& Wascher, D.M., Identification and characterization of 
environments and landscapes in Europe, Alterra, Wageninger, 119 pp., 2003

[2] Müller, K., Stream drift as a chronobiological phenomenon in running water ecosystems. Annual Review of Ecology and Systematics. 5, pp. 309323, 1974

[3] Radford, D.S. \& Hartland-Rowe, R., A Preliminary Investigation of Bottom Fauna and Invertebrate Drift in an Unregulated and a Regulated Stream in Alberta. The Journal of Applied Ecology. 8(3), pp. 883-903, 1971

[4] Elliott, J.M. \& Cornett J., The ecology of Morecambe bay: IV Invertebrate drift into and from the river leven. The Journal of Applied Ecology. 9(1), pp. 195-205, 1972

[5] Resh, V.H., Brown, A.V., Covich, A.P., Gurtz, M.E., Li, H.W., Minshall, G.W., Reice, S.R., Sheldon, A.L., Wallace, J.B \& Wissmar, R.C., The role of disturbance in stream ecology. Journal of the North American Benthological Society. 7(4), pp. 433-455, 1988

[6] Armitage, P.D., A quantitative study of the invertebrate fauna of the River Tees below Cow Green Reservoir. Freshwater Biology. 6(3), pp. 229-240, 1976

[7] Fritz, K.M. \& Dodds, W.K., Resistance and resilience of macroinvertebrate assemblages to drying and flood in a tallgrass prairie stream system. Hydrobiologia. 527, pp. 99-112, 2004

[8] Townsend, C.R. \& Hildrew, A.G., Species traits in relation to a habitat templet for river systems. Freshwater Biology, 31, pp. 265-275, 1994

[9] Statzner, B., Dolédec, S. \& Hugueny B., Biological trait composition of European stream invertebrate communities: assessing the effects of various filter types. Ecography. 27, pp. 470-488, 2004

[10] Statzner, B., Bady, P., Dolédec, S. \& Schöll, F., Invertebrate traits for the biomonitoring of large European rivers: an initial assessment of trait patterns in least impacted river reaches. Freshwater Biology. 50, pp. 21362161,2005

[11] Minns, C.K., Kelso, J.R. \& Randall, R.G., Detecting the response of fish habitat alterations in freshwater ecosystems. Canadian Journal of Fishery Aquatic Science. 53(1), pp. 403-414, 1996

[12] Karr, J., Rivers as sentinels: using the biology of rivers to guide landscape management (Chapter 20). Ecology and Management of Streams and Rivers in the Pacific Northwest Coastal Ecoregion, ed. Bilby, R.E. \& Naiman, R.J., Springer-Verlag, New York, 1998

[13] Boon, P.J., Impact of river regulations on invertebrate communities in the U.K. Regulated Rivers Research and Management. 2(3), pp. 389-409, 1988

[14] Bonada, N., Prat, N., Resh, V.H. \& Statzner, B., Development in aquatic insect biomonitoring: a comparative analysis of recent approaches. Annual Reviews of Entomology. 51, pp. 495-523, 2006 
[15] De Crespin, V. \& Usseglio-Polatera, P., Traits of brown trout prey in relation to habitat characteristics and benthic invertebrate communities. Journal of Fish Biology. 60, pp. 687-714, 2002

[16] Mérigoux, S. \& Dolédec, S., Hydraulic requirements of stream communities: a case study on invertebrates. Fresh water Biology. 49, pp. 600-613, 2004

[17] Alonso, J.A., Agostinho, J., Gomes, A., Barbosa, P., Santos, S., Rey, J., Paredes, C., Valin, I. \& Pereira, C., Os regimes hidrológicos, a hidrografia e o uso da água na bacia do rio Estorão e na Paisagem Protegida das Lagoas de Bertiandos e São Pedro d'Arcos. Instituto Politécnico de Viana do Castelo, Ponte de Lima, pp. 95, 2003

[18] Tachet, H., Richoux, P., Bournaud, M. \& Usseglio-Polatera, P., Invertébrés d'eau douce: systématique, biologie, écologie, CNRS Editions, Paris, pp. 553-577, 2000

[19] Usseglio-Polatera, P., Bournaud, M., Richoux, P. \& Tachet, H., Biomonitoring through biological traits of benthic macroinvertebrates: how to use species trait databases? Hydrobiologia. 422/423, pp. 153-162, 2000

[20] Sorensen, T., A method of establishing groups of equal amplitude in plant society based on similarity of species content. K. Danske Vidensk. Selk. 5, pp. 1-34, 1948

[21] Dolédec, S., Olivier, J. \& Statzner, B., Accurate description of abundance of taxa and their biological traits in stream invertebrate communities: effects of taxonomic and spatial resolution. Archive für Hydrobiologie. 148(1), pp. 25-43, 2000

[22] Chevenet, F., Dolédec, S. \& Chessel, D., A fuzzy coding approach for the analysis of long-term ecological data. Freshwater Biology. 47, pp. 295309, 1994

[23] Walker, K.F., A review of the ecological effects of river regulation in Australia. Hydrobiologia. 125(1), pp. 111-129, 1985

[24] Blinn, D.W. \& Cole, G.A., Algal and invertebrate biota in the Colorado River: comparison of Pre-and Post-dam conditions. Proc. of the Colorado River ecology and dam management symposium, National Academy Press: New Mexico, pp. 102-123, 1991

[25] Scarsbrook, M.R. \& Townsend, C.R., Stream community structure in relation to spatial and temporal variation: a habitat templet study of two contrasting New Zeeland streams. Freshwater Biology. 29, pp. 395-410, 1993

[26] Southwood, T.R., Habitat, the templet for ecological strategies? The Journal of Animal Ecology. 46(2), pp. 336-365, 1977

[27] Southwood, T.R., Tactics, strategies, and templets. Oikos. 52, pp. 3-18, 1988

[28] Townsend, C., The patch dynamics concept of stream community ecology. Journal of the North American Benthological Society. 8(1), pp. 36-50, 1989 
[29] Ladson A.R., White, L.J., Doolan, J.A., Finlayson, B.L., Hart, B.T., Lake, P.S. \& Tilleard, J.W., Development and testing of an index of stream conditions for waterway management in Australia. Freshwater Biology. 41, pp. 453-468, 1999

[30] Thompson, R. \& Townsend, C., A truce with neutral theory: local deterministic factors, species traits and dispersal limitation together determine patterns of diversity in stream invertebrates. Journal of Animal Ecology. 75, pp. 476-484, 2006

[31] Looman, J. \& Campbell, J.B., Adaptation of Sorensen's K (1948) of estimating unit affinities in prairie vegetation. Ecology. 41(3), pp. 409416, 1960

[32] Orth, R.J., Benthic infauna of Eelgrass, Zostera marina, Beds. Chesapeake Science. 14(4), pp. 258-269, 1973

[33] Corkum L.D., Spatial patterns of macroinvertebrate distribution along rivers in eastern delicious forests and grassland biomes. Journal of the North American Benthological Society. 10, pp. 113-116, 1991

[34] Bunn, S.E., Davies, P.M. \& Mosisch T.D., Ecosystem measures of river health and their response to riparian and catchment degradation. Freshwater Biology. 41, pp. 333-345, 1999

[35] Johnson, L.B., Richards, C., Host, G.E. \& Arthur J.W., Landscape influences on water chemistry in Midwestern stream ecosystems. Freshwater Biology. 37, pp. 113-132, 1997 